\title{
DETERMINATION OF HYDROXYPROLINE IN COLLAGEN BIOMATERIALS FOR MEDICAL USE AND VALIDATION OF METHOD
}

\author{
DETERMINAREA HIDROXIPROLINEI DIN BIOMATERIALELE COLAGENICE PENTRU UZ MEDICAL SI \\ VALIDAREA METODEI
}

\author{
Gabriela MACOVESCU*, Ciprian CHELARU, Mădălina Georgiana ALBU KAYA, Luminiţa ALBU
}

INCDTP - Division: Leather and Footwear Research Institute, 93 Ion Minulescu, 031215, Bucharest, Romania, icpi@icpi.ro

DETERMINATION OF HYDROXYPROLINE IN COLLAGEN BIOMATERIALS FOR MEDICAL USE AND VALIDATION OF METHOD

ABSTRACT. The paper presents a method for determining hydroxyproline in collagen biomaterials for medical use produced in The Collagen Department of INCDTP_ Division ICPI and its validation. The method has two stages: the first one consists in hydrolysis of proteins in the sample of protein product to the form of amino acids, among which hydroxyproline. The second stage refers to selective highlighting of hydroxyproline using a specific colour reaction and quantitative assessment against a reference standard with known concentration. The method was validated to establish performance parameter and to check compliance with the set goal. KEY WORDS: biomaterials, hydroxyproline, validation of method, collagen

\section{DETERMINAREA HIDROXIPROLINEI DIN BIOMATERIALELE COLAGENICE PENTRU UZ MEDICAL SI VALIDAREA METODEI}

REZUMAT. Lucrarea prezinta o metoda de determinare a hidroxiprolinei din biomaterialele colagenice pentru uz medical produse în Departamentul Colagen al INCDTP - Sucursala ICPI si validarea ei. Metoda are doua etape: prima consta în hidroliza proteinelor din proba de produs proteic pâna la stadiul de aminoacizi, printre care si hidroxiprolina. A doua etapa se refera la evidentierea selectiva a hidroxiprolinei printr-o reactie specifica de culoare si evaluarea cantitativa fata de un standard de referinta cu concentratie cunoscuta. Metoda a fost validata pentru a se stabili parametrii de performanta si pentru verificarea conformarii cu scopul propus.

CUVINTE CHEIE: biomateriale, hidroxiprolina, validare metoda, colagen

LA DÉTERMINATION DE L'HYDROXYPROLINE DANS LES BIOMATÉRIAUX DE COLLAGÈNE POUR UTILISATION MÉDICALE ET LA VALIDATION DE LA MÉTHODE RÉSUMÉ. Cet article présente une méthode de détermination de l'hydroxyproline dans les biomatériaux de collagène pour utilisation médicale produits dans le Département de Collagène de INCDTP - Division ICPI et la validation de cette méthode. La méthode comporte deux étapes: la première consiste en I'hydrolyse des protéines dans l'échantillon de produit protéique jusqu'à l'étape d'acides aminés, y compris l'hydroxyproline. La deuxième étape se réfère à la mise en évidence sélective de l'hydroxyproline par une réaction de couleur spécifique et à l'évaluation quantitative contre un étalon de référence de concentration connue. La méthode a été validée pour déterminer les paramètres de performance et pour vérifier la conformité avec le but fixé.

MOTS-CLÉS: biomatériaux, hydroxyproline, validation de la méthode, collagène

\section{INTRODUCTION}

The quality of products for medical use is a particularly complex concept because, unlike that of other industrial products, it has a much wider scope and much deeper effects. If for most industrial products quality is a well-defined property or set of physical-chemical properties, in the case of products for medical use, quality encompasses physicalchemical, biochemical, microbiological and toxicological characteristics. By their nature, these have profound implications on life, as they are an essential factor of metabolic processes and balance of the human body.

\section{INTRODUCERE}

Calitatea produselor pentru uz medical este un concept deosebit de complex deoarece, spre deosebire de cea a altor produse industriale, ea are un cuprins mult mai larg şi efecte mult mai profunde. Dacă pentru majoritatea produselor industriale, calitatea se caracterizează printr-o însuşire sau grup de însuşiri fizice şi chimice bine definite, în cazul produselor pentru uz medical calitatea înglobează caracteristici fizico-chimice, biochimice, microbiologice şi toxicologice. Acestea, prin calitatea lor, au implicaţii profunde asupra vieţii deoarece reprezintă un factor esenţial al proceselor metabolice şi al echilibrului organismului. 
Medical product manufacturers are responsible for the health of consumers, participating in one of the most effective health protection and promotion methods. As a result, products must fulfill three major requirements: i) therapeutic qualities; ii) hygiene qualities; iii) sensory qualities.

These requirements impose constant control by using complex and advanced methods that allow reliable and reproducible data.

Promoting such products requires the existence of relevant knowledge regarding the presence of biologically active compounds in the range of raw materials used and the assessment of their content in terms of functional components.

Due to its excellent biocompatibility and biodegradability, well-defined structure, biological characteristics and method of interaction with the body, collagen is one of the most frequently used biomaterials for medical treatment. Extracted in the form of aqueous solution or gel, type I fibrillar collagen may be modelled into various products: medical devices, artificial implants, drug release systems, creams and scaffolds for tissue regeneration, with important role in medicine [1-6].

Collagen itself is considered an active drug/ principle, used - in various forms - as hemostatic and dressing in the treatment of various types of wounds.

Collagen is the basis of intercellular matter of conjunctive tissue found in bones, teeth, cartilage, tendons, ligaments, skin, blood vessels and has an important role in a series of physiological processes, provides resistance and structural integrity to the body. An increase in catabolism and collagen regeneration are important information in the pathogenesis of many diseases.

Collagen, a natural protein, cannot heal infected tissue by itself, as bacteria may use it as a substrate. In severe wound infections, systemic drug administration may lead to insufficient drug concentration at the infected site or to side effects associated to the drug and/or systemic toxicity. This deficiency found its successful resolution in local drug applications, by developing drug release systems using collagen as substrate and an antibiotic/antiseptic as drug for infection control $[2,4,7,8]$.
Realizând produse pentru uz medical, producătorii sunt responsabili de starea de sănătate a consumatorilor, participând la una dintre cele mai eficiente căi de ocrotire şi promovare a sănătăţii. Ca urmare, produsele trebuie să fie sub imperiul a trei mari cerinţe: i) să posede calităţi terapeutice; ii) să posede calităţi igienice; iii) să posede calităţi senzoriale.

Aceste cerinţe impun un permanent control prin utilizarea unor metode complexe şi performante care să permită obţinerea unor date certe şi reproductibile.

Promovarea unor astfel de produse necesită existenţa unor cunoştinţe relevante privind prezenţa unor compuşi biologic activi în diversele materii prime utilizate şi evaluarea conţinutului lor în componentele care le conferă funcţionalitate.

Datorită biocompatibilităţii şi biodegradabilităţii excelente, a structurii bine definite, a caracteristicilor biologice şi a modului în care interacţionează cu organismul, colagenul reprezintă unul dintre cele mai utilizate biomateriale utilizate în tratamente medicale. Extras sub formă de soluţie apoasă sau gel, colagenul fibrilar tip I poate fi modelat în diferite forme: dispozitive medicale, implanturi artificiale, suporturi pentru cedarea medicamentelor, creme şi schelete pentru regenerare tisulară, cu un rol important în medicină [1-6].

Colagenul însuşi este considerat medicament/ principiu activ, fiind utilizat - sub diferite forme - ca hemostatic şi pansament în tratamentul diferitelor tipuri de leziuni.

Colagenul este baza materiei intercelulare a ţesutului conjunctiv prezent în oase, dinţi, cartilaje, tendoane, ligamente, tegument, vase de sânge şi are un rol important într-o serie de procese fiziologice, conferă organismului rezistenţă şi integritate structurală. O creştere a catabolismului şi regenerarea colagenului sunt informaţii importante în patogeneza multor boli.

Colagenul, fiind o proteină naturală, nu poate vindeca singură ţesutul infectat deoarece bacteriile îl pot utiliza ca substrat. În infecţiile severe ale rănilor, administrarea sistemică a medicamentelor poate conduce la o concentraţie insuficientă de medicament la locul infectat sau la efecte secundare asociate medicamentului şi/sau la toxicitate sistemică. Această deficienţă şi-a găsit rezolvarea cu succes în aplicaţiile locale ale medicamentelor, dezvoltându-se astfel sisteme de cedare care au ca suport colagenul şi ca medicament un antibiotic/antiseptic pentru controlul infecţiei $[2,4,7,8]$. 
The presence of collagen in the body is essential for healing minor skin injuries, as well as wounds in different tissues, for repairing cartilage, ligaments and bones, including even dental degeneration.

A natural polymer, collagen is made up of 20 amino acids, arranged in characteristic sequences that form a highly complex conformational structure, organized into four levels, called primary, secondary, tertiary and quaternary structures.

Collagen differs from regular proteins by the fact the it includes a higher concentration of certain amino acids. Almost a third of collagen composition is glycine, the smallest amino acid, and another third is proline and hydroxyproline, the active form of proline, an amino acid specific to collagen.

The most recent data regarding collagen composition shows that hydroxyproline residues are present in the major phenotype of type I collagen in a ratio of approximately $11.3 \mathrm{wt} \%$. The ratio of hydroxyprolyl residue in type II collagen from cartilage and in type IV collagen from basement membranes ranges from $12.9 \%$ and $14.3 \%$, and is approximately $15.0 \%$ in type III collagen $[9,10]$.

Hydroxyproline is an amino acid irreversibly synthesized from post translational hydroxylation of proline by prolyl hydroxylase. As hydroxyproline was found in very few proteins, other than collagen, hydroxyproline determination was used as a marker to quantify collagen and/or gelatin levels (from partial collagen hydrolysis resulting in a mixture of proteins and peptides).

Hydroxyproline determination is used to identify certain diseases that involve breakdown of collagen. Increased values of hydroxyproline have been correlated to bone metastasis, prostate carcinoma or hepatic fibrosis. Hydroxyproline dosing is also used in the food industry in quality control of meat and meat products [11].

Several experimental hydroxyproline determination approaches were found in the literature differing depending the nature of the material to be tested.

Tissue subjected to analyses are first hydrolysed with acid to release hydroxyproline. This is generally performed using hydrochloric acid solution $6 \mathrm{M}$ or sulphuric acid $6 \mathrm{M}$ at temperatures from 110 to $130^{\circ} \mathrm{C}$
Prezenţa colagenului în organism este esenţială pentru vindecarea rănilor uşoare ale pielii, dar şi a rănilor din diferite ţesuturi, pentru repararea cartilagiilor, ligamentelor şi oaselor, incluzând chiar şi degenerări dentare.

Polimer natural, colagenul este constituit din 20 de aminoacizi, aranjaţi în secvenţe caracteristice, ce formează o structură conformaţională foarte complexă, organizată pe patru nivele, numite structuri primară, secundară, terţiară şi cuaternară.

Colagenul diferă de proteinele obişnuite prin faptul că are în compoziţie o mai mare concentraţie de anumiţi aminoacizi. Aproape o treime din colagen este compusă din glicină, cel mai mic aminoacid şi o altă treime este formată din prolină şi hidroxiprolină, forma activă a prolinei, aminoacid specific colagenului.

Cele mai recente date privind compoziţia colagenului arată că reziduurile hidroxiprolinei sunt prezente în fenotipul major al colagenului tip I, în proporţie de aproximativ $11,3 \%$ în greutate. Ponderile reziduului hidroxiprolil din colagenul tip II din cartilaje şi colagenul tip IV din membranele bazale sunt cuprinse între $12,9 \%$ şi $14,3 \%$ şi sunt de aproximativ $15,0 \%$ în colagenul de tip III $[9,10]$.

Hidroxiprolina este un aminoacid care este sintetizat ireversibil din hidroxilarea post-translaţională a prolinei de către prolil hidroxilază. Deoarece hidroxiprolina a fost găsită în foarte puţine proteine, altele decât colagenul, măsurarea hidroxiprolinei a fost folosită ca un marker pentru a cuantifica nivelurile de colagen şi/sau gelatină (din hidroliza parţială a colagenului rezultând un amestec de proteine şi peptide).

Măsurarea hidroxiprolinei este utilizată pentru a identifica anumite boli care implică liza colagenului. Valori crescute ale hidroxiprolinei au fost corelate cu metastaze osoase, cu carcinom de prostată, sau cu fibroza hepatică. Dozarea hidroxiprolinei se utilizează şi în industria alimentară la controlul calitativ al cărnii şi al produselor din carne [11].

Pentru determinarea hidroxiprolinei, în literatura de specialitate au fost găsite mai multe abordări experimentale diferite în funcţie de natura materialului de testat.

Jesuturile supuse analizelor sunt mai întâi hidrolizate cu acid pentru a se elibera hidroxiprolina. Acest lucru este în general realizat folosind soluţie de acid clorhidric $6 \mathrm{M}$ sau acid sulfuric $6 \mathrm{M}$ la temperaturi 
for 10 to 24 hours, either in sealed tubes or in reflux condensers.

Other researchers used perchloric acid $72 \%$ at $100^{\circ} \mathrm{C}$ for $2-4$ hours $[12,13]$ or sulphuric acid $3 \mathrm{M}$ at $105^{\circ} \mathrm{C}$ for 16 hours, as specified in ISO 3496: 1994 for determination of hydroxyproline in meat and meat products [11].

Free hydroxyproline is most conveniently quantified colorimetrically after oxidation to pyrrole, which is then reacted specifically with $p$ dimethylaminobenzaldehyde (Ehrlich's reagent) to produce an intense red-brown compound. Chloramine-T is now generally preferred as oxidant in pyrrole formation.

In the case of collagen-rich foodstuff, three methods are most used, but the most often used is the one proposed by the International Standard Organization in ISO 3496:1994 that was developed specifically for determining hydroxyproline in meat or meat products.

For routine analysis, the amino analyzer is a convenient means for treating a large number of samples. Also, for medical analyses of bodily fluids (blood, urine, plasma) rapid, but not economical, methods have been developed using kits.

After acid hydrolysis of the collagen material, several methods may be used for the quantitative determination of 3-hydroxyproline and 4-hydroxyproline by high-performance liquid-chromatography [14-16], or by gas chromatography using volatile derivatives, such as esters $[17,12,13]$, trifluoroacetyl-butyl or isobutyl, or Nheptafluorobutyryl [18], laborious methods which are suitable for low contents in the samples.

The most frequently used is still the spectrophotometric method for the determination of hydroxyproline, based on the reaction with Ehrlich's reagent [19-24].

The chemical mechanism of this process can be described as follows: the structure of hydroxyproline contains a pyrrolidine ring, which may undergo oxidative dehydration to a pyrrole ring, which may be subsequently identified through a reaction with Ehrlich's reagent or p-dimethylaminobenzaldehyde. The resulting quinoid compound is intensely colored (color depends on the substituents and ranges from orange to purple). cuprinse între $110-130^{\circ} \mathrm{C}$ timp de 10 până la 24 ore, fie în tuburi sigilate, fie sub reflux cu condensator de aer.

Alţi cercetători au folosit acid percloric $72 \%$ la $100^{\circ} \mathrm{C}$ timp de $2-4$ ore $[12,13]$ sau acid sulfuric $3 \mathrm{M} \mathrm{la}$ $105^{\circ} \mathrm{C}$ timp de 16 ore, cum este specificat în ISO 3496: 1994 pentru determinarea hidroxiprolinei din carne şi din produse din carne [11].

Hidroxiprolina liberă este cuantificată cel mai convenabil colorimetric după oxidarea la pirol, care este apoi reacţionat în mod specific cu p-dimetil-amino benzaldehidă (reactivul Ehrlich) pentru a produce un compus intens de culoare roşu-brun. Cloramina T este acum în general preferată pentru utilizarea ca oxidant în formarea pirolului.

Pentru materialele alimentare bogate în colagen, cel mai mult sunt folosite trei metode, dar cea mai uzitată este cea propusă de Organizaţia Internaţională pentru Standarde în ISO 3496: 1994 care a fost dezvoltată în mod special pentru determinarea hidroxiprolinei din carne sau produse din carne.

Pentru analize de rutină aminoanalizorul reprezintă un mijloc convenabil pentru tratarea unui număr mare de probe. De asemenea, pentru analizele medicale din lichide fiziologice (sânge, urină, plasmă) s-au dezvoltat metode rapide, dar nu prea economice, care folosesc kituri.

După hidroliza acidă a materialului colagenic există mai multe metode publicate pentru determinarea cantitativă sensibilă prin cromatografie lichidă de înaltă performanţă a 3-hidroxiprolină şi 4-hidroxiprolină [13-15] sau prin cromatografie de gaz folosind derivaţi volatili, cum ar fi esteri $[17,12,13]$, trifluoracetil de butil sau izobutil sau $\mathrm{N}$-heptafluorbutiril [18], metode laborioase şi care se pretează pentru conţinuturi reduse în probe.

Cea mai uzitată metodă rămâne însă metoda de determinare spectrofotometrică a hidroxiprolinei care se bazează pe reacţia cu reactiv Ehrlich [19-24].

Mecanismul chimic al acestui proces poate $\mathrm{fi}$ descris după cum urmează: hidroxiprolina conţine în structură un inel de pirolidină, care poate suferi oxidativ o dehidrogenare până la un inel de pirol, care poate fi identificat ulterior folosind o reacţie cu reactiv Ehrlich sau p-dimetilaminobezaldehidă. Compusul quinoid rezultat este intens colorat (culoarea depinde de substituenţi şi variază de la portocaliu la lila). 
The use of compounds such as hydrogen peroxide, Chloramine-B or Chloramine- $T$ is reported in the literature for oxidative dehydrogenation [24-26].

As a result of the literature review on methods for the determination of hydroxyproline in tissues, meat and meat products, bodily fluids and various types of collagen, the method presented below was adapted and used for protein-based products intended for medical use.

\section{MATERIALS AND METHOD}

\section{Method Principle}

Hydroxyproline determination is performed taking into account the following three basic steps:

a) hydroxyproline is derivatized from collagen by hydrolysis with sulphuric acid, at high temperature, $105^{\circ} \mathrm{C}$;

b) hydroxyproline is oxidized by adding Chloramine-T, and the oxidation product is subjected to decarboxylation to pyrrole, in an acid medium at high temperature;

c) pyrrole combines, in an acid medium, with $p$ dimethylaminobenzaldehyde (DMAB) and the resulting addition product is determined by measuring the solution absorbance at $558 \mathrm{~nm}$.

Hydroxyproline content is calculated and expressed as mass percentage.

\section{Reagents}

Only known analytical grade reagents (SIGMA ALDRICH) and distilled water, demineralized water or water equivalent in purity are used.

1. Sulphuric acid solution, $3 \mathrm{~mol} / \mathrm{L}$.

2. Buffer solution, $\mathrm{pH}=6.8$, consisting of:

- 26.0 g citric acid monohydrate;

- 14.0 g sodium hydroxide;

- 78.0 g sodium acetate anhydrous

Reagents are dissolved in $500 \mathrm{~mL}$ water and quantitatively transferred in a 1 litre volumetric flask. $250 \mathrm{~mL} \mathrm{~N}$-propanol are added and water is filled up to the mark. When stored at the temperature of $4^{\circ} \mathrm{C}$ in the dark, this solution is stable up to a few weeks.
Pentru dehidrogenarea oxidativă, în literatură se utilizează compuşi ca perhidrol, Cloramina B sau Cloramina T [24-26].

Ca urmare a studiului de literatură privind metodele de determinare a hidroxiprolinei din ţesuturi, din carne şi produse din carne, din lichide fiziologice şi din diferitele tipuri de colagen, $\mathrm{s}$-a făcut $\mathrm{o}$ adaptare a metodei care este expusă mai jos şi s-a folosit pentru produsele proteice pentru uz medical.

\section{MATERIALE ŞI METODĂ}

\section{Principiul metodei}

Determinarea hidroxiprolinei se efectuează luând în considerare următoarele trei etape de bază:

a) hidroxiprolina este derivatizată din colagen prin hidroliză cu acid sulfuric, la temperatură ridicată, $105^{\circ} \mathrm{C}$;

b) hidroxiprolina este oxidată prin adăugarea de Cloramină-T, iar produsul de oxidare este supus, într-un mediu acid, la temperatură ridicată, decarboxilării la pirol;

c) pirolul se combină, într-un mediu acid, cu pdimetilaminobezaldehidă (DMAB) şi produsul de adiţie obţinut este determinat prin măsurarea absorbanţei soluţiei la $558 \mathrm{~nm}$.

Conţinutul de hidroxiprolină este calculat şi exprimat ca procente de masă.

\section{Reactivi}

Se utilizează numai reactivi de calitate analitică recunoscută (SIGMA ALDRICH) şi apă distilată sau apă demineralizată sau apă echivalentă ca puritate.

1. Soluţie de acid sulfuric, $3 \mathrm{~mol} / \mathrm{l}$.

2. Soluţie tampon, $\mathrm{pH}=6,8$, constând din:

- 26,0 g acid citric monohidrat;

- 14,0 g de hidroxid de sodiu;

- 78,0 g de acetat de sodiu anhidru.

Se dizolvă reactivii în $500 \mathrm{ml}$ de apă şi se transferă cantitativ într-un balon cotat de 1 litru. Se adaugă $250 \mathrm{ml}$ de N-propanol şi se completează până la marcaj cu apă. Când este depozitată la temperatura de $4^{\circ} \mathrm{C}$ în întuneric, această soluţie este stabilă timp de câteva săptămâni. 


\section{Chloramine-T}

$1.41 \mathrm{~g} \mathrm{~N}$-chloro-p-toluenesulfonamide sodium salt trihydrate (Chloramine-T) are dissolved in $100 \mathrm{~mL}$ buffer solution. This solution is prepared immediately before use.

\section{Colour reagent}

$10.0 \mathrm{~g}$ p-dimethylaminobenzaldehyde are dissolved in $35 \mathrm{~mL}$ perchloric acid solution [60\% $(\mathrm{m} / \mathrm{m})]$ and then $65 \mathrm{~mL}$ isopropanol are slowly added. This solution is prepared on the day it is used.

\section{Hydroxyproline, standard solutions}

A stock solution is prepared by dissolving $50 \mathrm{mg}$ hydroxyproline in water in a $100 \mathrm{~mL}$ volumetric flask. 1 drop sulphuric acid solution is added and filled up to the mark with water. This solution is stable for at least 1 month, stored at $4^{\circ} \mathrm{C}$.

On the day of use, $5 \mathrm{~mL}$ stock solution is transferred into a $500 \mathrm{~mL}$ volumetric flask and filled up to the mark with water. Four standard solutions are then prepared by diluting $10 \mathrm{~mL}, 20 \mathrm{~mL}, 30 \mathrm{~mL}$ and 40 $\mathrm{mL}$ of this solution with water up to $100 \mathrm{ml}$ to obtain hydroxyproline concentrations of $0.5 \mu \mathrm{g} / \mathrm{mL}, 1 \mu \mathrm{g} / \mathrm{mL}$, $1.5 \mu \mathrm{g} / \mathrm{mL}$, and $2 \mu \mathrm{g} / \mathrm{mL}$, respectively.

\section{Equipment}

- Spectrometer, suitable for use at a wavelength of $558 \mathrm{~nm} \pm 2 \mathrm{~nm}$, or a photoelectric colorimeter with an interference filter with maximum absorption at $558 \mathrm{~nm} \pm 2 \mathrm{~nm}$. Glass cells with optical path length of $10 \mathrm{~mm}$ are used.

- Adjustable oven at $105^{\circ} \mathrm{C} \pm 2^{\circ} \mathrm{C}$;

- Analytical scales with accuracy of $0.0001 \mathrm{~g}$

- Adjustable water bath at $60^{\circ} \mathrm{C}$

\section{Work Method}

Sample Preparation

a. Approximately 0.5-1 g sample are weighed with an accuracy of $0.0001 \mathrm{~g}$ in hydrolysis tubes so that the sample does not adhere to the walls.

b. $10 \mathrm{~mL}$ sulphuric acid solution (1) are added, the tube is covered and placed in the oven at $105^{\circ} \mathrm{C}$ $\pm 2^{\circ} \mathrm{C}$ for 16 hours for hydrolysis.

\section{Cloramină-T}

Se dizolvă 1,41 g sare de sodiu a N-clor-ptoluensulfonamidă trihidrat (Cloramina-T) în $100 \mathrm{ml}$ din soluţia tampon. Această soluţie se prepară imediat înainte de utilizare.

\section{Reactiv de culoare}

Se dizolvă 10,0 g p-dimetilaminobezaldehidă în 35 $\mathrm{ml}$ de soluţie de acid percloric $[60 \%(\mathrm{~m} / \mathrm{m})]$ şi apoi se adaugă încet $65 \mathrm{ml}$ de izopropanol. Această soluţie se prepară în ziua utilizării.

\section{Hidroxiprolină, soluţii standard.}

Se obţine o soluţie stoc prin dizolvarea a $50 \mathrm{mg}$ de hidroxiprolină în apă într-un balon cotat de 100 ml. Se adaugă 1 picătură de soluţie de acid sulfuric şi se completează până la semn cu apă. Această soluţie este stabilă timp de cel puţin 1 lună, la $4^{\circ} \mathrm{C}$.

În ziua de utilizare, se transferă $5 \mathrm{ml}$ de soluţie stoc într-un balon cotat de $500 \mathrm{ml}$ şi se completează până la semn cu apă. Apoi se prepară patru soluţii standard prin diluarea a $10 \mathrm{ml}, 20 \mathrm{ml}, 30 \mathrm{ml}$ şi $40 \mathrm{ml}$ din această soluţie până la $100 \mathrm{ml}$ cu apă pentru a obţine concentraţiile hidroxiprolinei de $0,5 \mu \mathrm{g} / \mathrm{ml}, 1 \mu \mathrm{g} / \mathrm{ml}, 1,5$ $\mu \mathrm{g} / \mathrm{ml}$ şi respectiv $2 \mu \mathrm{g} / \mathrm{ml}$.

\section{Aparatură}

- Spectrometru, adecvat pentru utilizare la o lungime de undă de $558 \mathrm{~nm} \pm 2 \mathrm{~nm}$, sau un colorimetru fotoelectric cu un filtru de interferenţă cu un maxim de absorbţie la 558 $\mathrm{nm} \pm 2 \mathrm{~nm}$. Se folosesc celule de sticlă cu drum optic de $10 \mathrm{~mm}$.

- Etuvă reglabilă la $105^{\circ} \mathrm{C} \pm 2^{\circ} \mathrm{C}$;

- Balanţă analitică cu acurateţea de 0,0001 g;

- Baie de apă reglabilă la $60^{\circ} \mathrm{C}$.

\section{Mod de lucru}

\section{Pregătirea probei}

a. Se cântaresc aproximativ 0,5-1 g de proba cu acuratete de 0,0001 g în tuburi de hidroliza astfel încât proba sa nu adere la pereti.

b. Se adauga $10 \mathrm{ml}$ solutie de acid sulfuric (1), se acopera tubul si se plaseaza în etuva la $105^{\circ} \mathrm{C} \pm$ $2^{\circ} \mathrm{C}$ timp de 16 ore pentru hidroliza. 
c. The resulting hydrolysate is transferred into a $250 \mathrm{~mL}$ volumetric flask and filled with water up to the mark.

d. Using a pipette, a volume $\mathbf{V}$ is added into a 250 $\mathrm{mL}$ volumetric flask and filled with water up to the mark. Volume $\mathrm{V}$ will be taken so that hydroxyproline content would range between $0.5 \mu \mathrm{g} / \mathrm{mL}$ and $2 \mu \mathrm{g} / \mathrm{mL}$.

e. $4.00 \mathrm{~mL}$ of this solution (d) is transferred into a test tube and $2.00 \mathrm{~mL}$ Chloramine-T reagent is added (3). The solution is stirred and left at room temperature for $20 \mathrm{~min} \pm 1 \mathrm{~min}$.

f. $2.00 \mathrm{~mL}$ colour reagent (4) is added, mixed thoroughly and the lid of the tube is covered with aluminium or plastic foil (5.6).

g. The tube is rapidly transferred into the water bath (5.7), set at $60^{\circ} \mathrm{C}$ and heated for 20 minutes precisely.

h. The tube is cooled under tap water stream for at least 3 minutes and left at room temperature for $30 \mathrm{~min}$.

i. Absorbance is measured at $558 \mathrm{~nm} \pm 2 \mathrm{~nm}$ in a glass cell compared to a blank of reagents.

\section{Calibration Curve}

The procedure described from item e. to i. included is performed on standard hydroxyproline using $4.00 \mathrm{ml}$ of the four diluted solutions.

The calibration curve is plotted.

Values for analysed samples are read and concentration is calculated depending on the mass of the sample, dilutions and the sample volume $\mathbf{V}$ taken in item d.

\section{RESULTS AND DISCUSSIONS}

Collagen biomaterials for medical use from the Collagen Department of INCDTP - Division ICPI, namely collagen hydrolysates, gels and matrices used in wound treatment (Pancol, Gevicol), were studied to determine hydroxyproline [5-9].

Samples were physically-chemically characterised and the results are presented in Table 1: c. Hidrolizatul obtinut se transfera într-un balon cotat de $250 \mathrm{ml}$ si se aduce la semn cu apa.

d. $\mathrm{Cu}$ ajutorul unei pipete se introduce un volum V într-un balon cotat de $250 \mathrm{ml}$ şi se aduce la semn cu apă. Volumul V va fi luat astfel încât conţinutul de hidroxiprolină să fie cuprins în intervalul $0,5 \mu \mathrm{g} / \mathrm{ml}-2 \mu \mathrm{g} / \mathrm{ml}$.

e. Se transfera $4,00 \mathrm{ml}$ din aceasta solutie (d) întro eprubeta si se adauga $2,00 \mathrm{ml}$ de reactiv Cloramina-T (3). Se amesteca si se lasa la temperatura camerei timp de $20 \mathrm{~min} \pm 1 \mathrm{~min}$.

f. Se adauga $2,00 \mathrm{ml}$ reactiv de culoare (4), se amesteca bine si capacul tubului se acopera cu aluminiu sau folie de plastic (5.6).

g. Se transfera tubul rapid în baia de apa (5.7), stabilita la $60^{\circ} \mathrm{C}$ si se încalzeste timp de exact 20 de minute.

h. Se raceste tubul sub jet de apa de la robinet timp de cel putin 3 minute si se lasa la temperatura camerei timp de $30 \mathrm{~min}$.

i. Se masoara absorbanta la $558 \mathrm{~nm} \pm 2 \mathrm{~nm}$ într-o celula de sticla fata de un blank de reactivi.

Curba de calibrare

Se efectuează procedura descrisă de la punctul e. până la i. inclusiv, cu câte $4,00 \mathrm{ml}$ din cele patru soluţii diluate hidroxiprolinei standard.

Se traseaza graficul de calibrare.

Se citesc valorile pentru probele luate în lucru şi se calculează concentraţia în funcţie de masa probei, diluţiile efectuate şi volumul $\mathbf{V}$ de probă luat la punctul d.

\section{REZULTATE SI DISCUTII}

Pentru determinarea hidroxiprolinei s-au luat în studiu biomateriale colagenice pentru uz medical de la Departamentul Colagen al INCDTP - Sucursala ICPI, respectiv hidrolizate, geluri şi matrici colagene folosite la tratarea plăgilor (Pancol, Gevicol) [5-9].

Probele au fost caracterizate fizico-chimic, rezultatele fiind prezentate în Tabelul 1: 
Table 1: Characterization of collagen biomaterials for medical use

Tabelul 1: Caracterizarea biomaterialelor colagenice pentru uz medical
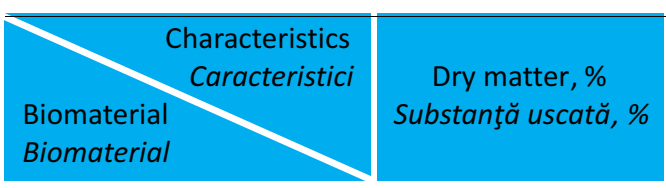

\begin{tabular}{|c|}
\hline $\begin{array}{c}\text { Pancol batch } 2 \\
\text { Pancol lot } 2\end{array}$ \\
\hline Pancol batch 3 \\
Pancol lot 3 \\
\hline Gevicol batch 2 \\
Gevicol lot 2 \\
Gevicol batch 3 \\
Gevicol lot 3 \\
\hline
\end{tabular}

Collagen gel batch 2 Gel colagen lot 2

Collagen gel batch 3
Gel colagen lot 3

Hydrolysate COL 22 Hidrolizat COL 22

\section{Hydrolysate COL 23} Hidrolizat COL 23

\begin{tabular}{|l|}
\hline 85.79 \\
\hline 84.30 \\
\hline 87.57 \\
\hline 86.52 \\
\hline 2.95 \\
\hline 4.43 \\
\hline 84.90 \\
\hline
\end{tabular}

*values are recalculated without volatile matter

*valorile sunt recalculate la liber de materii volatile
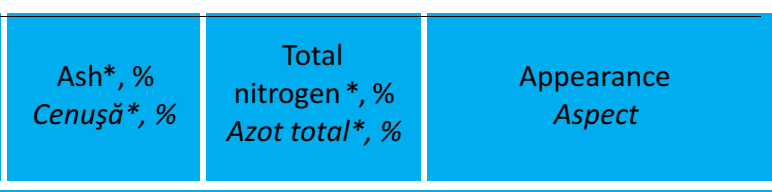

\begin{tabular}{|l|l|}
\hline 1.64 \\
\hline 2.90 \\
\hline 2.72 \\
\hline 1.46 \\
\hline 4.07 \\
\hline 2.48 \\
\hline 2.01 \\
\hline
\end{tabular}

\begin{tabular}{|l|}
\hline 15.78 \\
\hline 16.20 \\
\hline 16.45 \\
\hline 14.80 \\
\hline 17.28 \\
\hline 15.08 \\
\hline 16.87 \\
\hline 17.15 \\
\hline
\end{tabular}

Spongious white foil Folie albă spongioasă

Spongious white foil Folie albă spongioasă

Spongious violet foil Folie violet spongioasă

Spongious violet foil Folie violet spongioasă

\begin{tabular}{|c|}
\hline Transparent gel \\
Gel transparent \\
\hline Transparent gel \\
Gel transparent \\
\hline Yellowish powder \\
Pulbere gălbui \\
\hline Yellowish powder \\
Pulbere gălbui \\
\hline
\end{tabular}

Chloramine-T ( $\mathrm{N}$-chloro-4-toluenesulfonamide sodium salt) was used as oxidation agent, as its indisputable advantages include easy decomposition of its excess and absence of coloured reduction products. The oxidation reaction is performed in a buffer solution with $\mathrm{pH} \sim 6.8$.

Hydroxyproline oxidation is illustrated by the following reactions:
Cloramina-T (sarea de sodiu N-clor-4toluensulfonamida) a fost utilizată ca agent de oxidare deoarece printre avantajele incontestabile ale acestui agent de oxidare sunt uşurinţa de descompunere a excesului său şi absenţa produselor de reducere colorate. Reacţia de oxidare este realizată într-o soluţie tampon cupH $\sim 6,8$.

Oxidarea hidroxiprolinei este ilustrată prin reacţiile următoare:

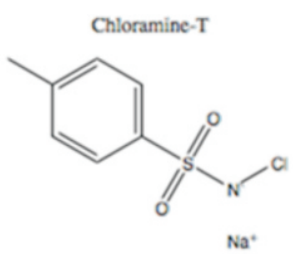

The postulated mechanism for the oxidation of hydroxyproline to pyrrole is as follows (2): first hydroxyproline (I) is oxidized to a linear compound, $\alpha$ keto- $\gamma$-hydroxy- $\delta$-aminovaleric acid (II), which is in equilibrium with the pyrroline-4-hydroxy -2-carboxylic acid with cyclic structure (III). The loss of water gives an

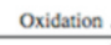

\section{Product A}

Mecanismul postulat pentru oxidarea hidroxiprolinei la pirol este următorul (2): mai întâi hidroxiprolina (I) este oxidată la un compus liniar, acidul $\alpha$-ceto- $\gamma$-hidroxi- $\delta$-aminovaleric (II), care se află în echilibru cu acidul pirolin-4-hidroxi-2-carboxilic cu structură ciclică (III). Pierderea de apă dă o structură 
unstable structure (IV), which spontaneously rearranges to pyrrole-2-carboxylic acid (V). The final step of decarboxylation to pyrrole (VI) takes place during the heating after the addition of the chromogenic reagent for pyrrole, p-dimethylaminobenzaldehyde [27]. instabilă (IV), care se rearanjează spontan la pirol-2carboxilic (V). Etapa finală de decarboxilare la pirol (VI) are loc în timpul încălzirii după adăugarea reactivului cromogen pentru pirol, respectiv pdimetilaminobenzaldehida [27].

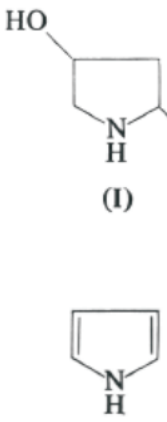

(VI)

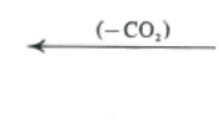

Chromophore formation is illustrated in the following reaction:

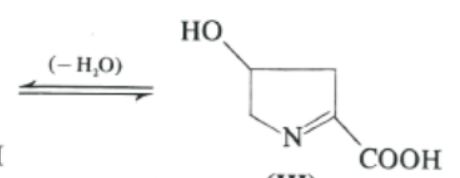

(III)<smiles>C[Y](C)(C)CO</smiles>

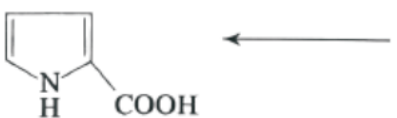

(V)

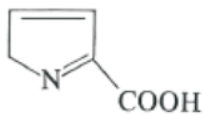

(IV)

Formarea cromoforului cu este ilustrată în reacţia următoare:<smiles></smiles>

As the products tested have a much higher collagen content, the amount of sample tested was modified. Also, as the product in question is collagen hydrolysate, we considered it necessary to use more diluted mineral acids for hydrolysis, namely 3 molar compared to the 6-12 molar used for meat and meat products. The hydrolysate filtration step was eliminated as it does not contain other components.

Both sulphuric acid $3 \mathrm{M}$ and hydrochloric acid $3 \mathrm{M}$ were used for hydrolysis of studied samples, with comparable results.

Values for hydroxyproline in collagen products for medical use determined using the adapted method are in accordance with literature data regarding hydroxyproline content. Each value is the average of 10 replicated determinations, presented in Table 2.
Pentru că produsele luate în studiu au o cantitate mult mai mare de colagen, s-a modificat cantitatea de probă luată în lucru. De asemenea, fiind vorba de hidrolizate de colagen, am considerat necesar a se utiliza pentru hidroliză acizi minerali mai diluaţi, respectiv 3 molar faţă de 6-12 molar, cât se utilizează pentru carne şi produse din carne. S-a eliminat faza de filtrare a hidrolizatului deoarece nu avem alte componente.

Pentru hidroliza probelor luate în studiu s-a utilizat atât acid sulfuric $3 \mathrm{M}$, cât şi acid clorhidric $3 \mathrm{M}$, rezultatele fiind comparabile.

Valorile pentru hidroxiprolina din produsele colagenice pentru uz medical determinate prin metodă adaptată sunt în concordanţă cu datele din literatură privind conţinutul de hidroxiprolină. Valorile se regăsesc în Tabelul 2, fiecare valoare reprezentând media a zece determinări replicate. 
Table 2: Hydroxyproline content of collagen biomaterials for medical use

Tabelul 2: Conţinutul de hidroxiprolină al biomaterialelor colagenice pentru uz medical

\begin{tabular}{|c|c|c|c|c|c|c|c|c|}
\hline $\begin{array}{l}\text { Biomaterial } \\
\text { Biomaterial }\end{array}$ & $\begin{array}{l}\text { Pancol } \\
\text { batch } 2 \\
\text { Pancol } \\
\text { lot } 2\end{array}$ & $\begin{array}{l}\text { Pancol } \\
\text { batch } 3 \\
\text { Pancol } \\
\text { lot } 3\end{array}$ & $\begin{array}{l}\text { Gevicol } \\
\text { batch } 2 \\
\text { Gevicol } \\
\text { lot } 2\end{array}$ & $\begin{array}{l}\text { Gevicol } \\
\text { batch } 3 \\
\text { Gevicol } \\
\text { lot } 3\end{array}$ & $\begin{array}{l}\text { Collagen gel } \\
\text { batch } 2 \\
\text { Gel colagen } \\
\text { lot } 2\end{array}$ & $\begin{array}{l}\text { Collagen gel } \\
\text { batch } 3 \\
\text { Gel colagen } \\
\text { lot } 3\end{array}$ & $\begin{array}{l}\text { Hydrolysate } \\
\text { COL } 22 \\
\text { Hidrolizat } \\
\text { COL } 22\end{array}$ & $\begin{array}{l}\text { Hydrolysate } \\
\text { COL } 23 \\
\text { Hidrolizat } \\
\text { COL } 23\end{array}$ \\
\hline $\begin{array}{l}\text { Hydroxyproline, \% } \\
\text { Hidroxiprolină, \% }\end{array}$ & 13.98* & $14.23^{*}$ & $14.63^{*}$ & $14.55^{*}$ & $15.01 *$ & $15.12^{*}$ & $12.51^{*}$ & $12.77^{*}$ \\
\hline
\end{tabular}

Validation is, therefore, an important step in determining repeatability, reproducibility and safety of the method, as it confirms whether the method is suitable for use in a given system.

Throughout the validation stages of the method, several performance parameters are monitored: limit of detection (LOD), limit of quantification (LOQ), linearity, working range, accuracy, reliability, repeatability, internal reproducibility.

The validation method and analysis procedure of hydroxyproline content were performed in accordance to EURACHEM validation guide for analytical methods.

Working range is the interval between the lower concentration and the higher concentration of the analyte in the sample for which it was proven that the procedure has the right level of precision, accuracy and linearity.

Linearity is the ability of an analytical method to yield results proportional to the concentration of the analyte in the sample.

The calibration curve of hydroxyproline was plotted in the range of $0.1-2.5 \mu \mathrm{g} / \mathrm{mL}$ and the linearity range for which the correlation coefficient characterizing the regression line R2 $=0.990377$ was visually assessed.
Validarea este, aşadar, o etapă importantă în determinarea repetabilităţii, reproductibilităţii şi siguranţei metodei, deoarece poate confirma dacă metoda este potrivită pentru a fi utilizată pentru un anumit sistem.

Pe parcursul etapelor validării metodei de analiză se urmăresc mai mulţi parametri de performanţă ai metodei: limita de detecţie (LOD), limita de cuantificare (LOQ), liniaritatea, domeniul concentraţiilor de lucru, exactitatea, fidelitatea, repetabilitatea, reproductibilitatea internă.

Metoda de validare şi procedura de analiză a conţinutului de hidroxiprolină s-a realizat în conformitate cu ghidurile de validare pentru metodele analitice EURACHEM.

Domeniul concentraţiilor de lucru reprezintă intervalul dintre concentraţia inferioară şi cea superioară a analitului din proba de analizat pentru care s-a demonstrat că procedura are un nivel potrivit de precizie, exactitate şi liniaritate.

Liniaritatea reprezintă abilitatea unei metode analitice de a obţine rezultate proporţionale cu concentraţia analitului din probă.

S-a trasat curba de etalonare a hidroxiprolinei pe domeniul 0,1-2,5 $\mu \mathrm{g} / \mathrm{ml}$ şi s-a examinat vizual domeniul de liniaritate pentru care s-a obţinut coeficientul de corelaţie ce caracterizează dreapta de regresie $\mathrm{R} 2=0,990377$. 


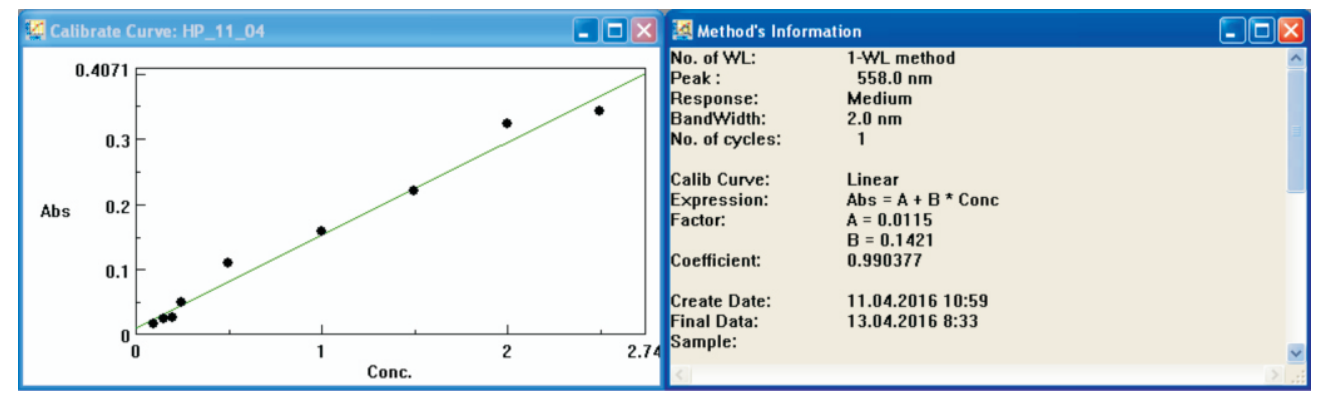

Figure 1. Linearity range for concentrations ranging between $0.1 \mu \mathrm{g} / \mathrm{mL}$ and $2.5 \mu \mathrm{g} / \mathrm{mL}$

Figura 1. Domeniu de liniaritate pentru concentraţii cuprinse între $0,1 \mu \mathrm{g} / \mathrm{ml}$ şi $2,5 \mu \mathrm{g} / \mathrm{ml}$

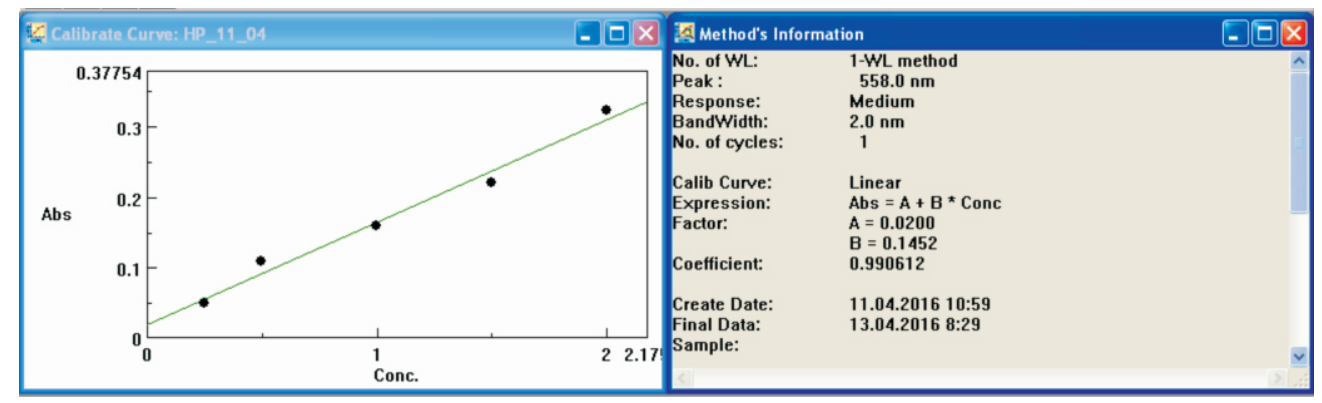

Figure 2. Linearity range for concentrations ranging between $0.5 \mu \mathrm{g} / \mathrm{mL}$ and $2 \mu \mathrm{g} / \mathrm{mL}$

Figura 2. Domeniu de liniaritate pentru concentraţii cuprinse între $0,5 \mu \mathrm{g} / \mathrm{ml}$ şi $2 \mu \mathrm{g} / \mathrm{ml}$

The equation of the linear regression function is:

Ecuaţia funcţiei de regresie liniară este de forma:

$$
\begin{gathered}
y=0.1421 x+0.0115 \\
b=0.0115 \text { intensity units } x \mu g^{-1} \mid
\end{gathered}
$$

$$
R^{2}=0.9908
$$

For good linearity, the correlation coefficient characterizing the regression line must range between 0.990 and 1.

Ten replicated samples of $1.5 \mu \mathrm{g} / \mathrm{mL}$ hydroxyproline concentration were prepared and $\mathrm{Yi}$ values were measured (integrated units) for signal intensity at $558 \mathrm{~nm}$. Based on the equation of the calibration curve, $\mathrm{Xi}(\mu \mathrm{g} / \mathrm{L})$ values of concentration obtained experimentally were calculated and are presented in Table 3.
Pentru o bună liniaritate, coeficientul de corelaţie ce caracterizează dreapta de regresie trebuie sa fie cuprins între 0,990 şi 1.

S-au preparat 10 probe replicate de concentraţie $1,5 \mu \mathrm{g} / \mathrm{ml}$ hidroxiprolină şi s-au măsurat valorile $\mathrm{Yi}$ (unităţi integrate) ale intensităţii semnalului de la 558 $\mathrm{nm}$. Pe baza ecuaţiei curbei de etalonare s-au determinat prin calcul valorile Xi $(\mu g / l)$ de concentraţie obţinute experimental şi sunt prezentate în Tabelul 3. 
Table 3: $Y i$ and $\mathrm{Xi}$ values obtained for the ten analysed samples

Tabelul 3: Valorile Yi şi Xi obţinute pentru cele 10 probe analizate

\begin{tabular}{c|c|c|c|c|c|c|c|c|c|c|c} 
& 1 & 2 & 3 & 4 & 5 & 6 & 7 & 8 & 9 & 10 \\
\hline $\mathrm{Yi}$ & 0.2245 & 0.2249 & 0.2246 & 0.2247 & 0.2241 & 0.2250 & 0.2255 & 0.2251 & 0.2253 & 0.2250 \\
\hline $\mathrm{Xi}$ & 1.4877 & 1.4906 & 1.4885 & 1.4892 & 1.4848 & 1.4913 & 1.4949 & 1.4921 & 1.4935 & 1.4913 \\
\hline
\end{tabular}

$X_{\text {average }}($ det. $)=1.4904 \mu \mathrm{g} / \mathrm{L}$

$\mu=$ real value of the reference material

Accuracy is the closeness between the real value and the value determined in the analysed sample and is calculated using the following formula:
$X_{\text {mediu }}($ det. $)=1,4904 \mu \mathrm{g} / \mathrm{I}$

$\mu=$ valoarea reală a materialului de referinţă

Exactitatea reprezintă apropierea dintre valoarea reală şi valoarea găsită în proba de analizat şi se calculează cu formula:

$$
\begin{aligned}
\text { Accuracy/Exactitate } \% & =\frac{X_{\text {mediu }}}{\mu} 100 \\
\text { Bias } \% & =\frac{X_{\text {mediu }}-\mu}{\mu} 100 \quad \text { Bccuracy/Exactitate }=\frac{1,4904}{1,5}=99,36 \% \\
& \text { Bias }=0.64 \%
\end{aligned}
$$

The performance criterion established for accuracy was to fall in the $95-105 \%$ range and the determined value is $99.36 \%$.

Standard deviation $\mathrm{s}=0.00295 \mu \mathrm{g} / \mathrm{mL}$

$\mathrm{CV}(\mathrm{RSD})=0.19766 \%$

Repeatability is a measure of the scattering degree, in a confidence interval, of the results obtained from measurement performed by the same analyst, under the same working conditions.
Criteriul de performanţă stabilit pentru exactitate a fost să se încadreze în intervalul 95-105\% şi valoarea găsită este de $99,36 \%$.

Deviaţia standard s=0,00295 $\mu \mathrm{g} / \mathrm{ml}$

CV (RSD) $=0,19766 \%$

Repetabilitatea este o măsură a gradului de împrăştiere, într-un interval de încredere, a rezultatelor obţinute în urma măsurării executate de acelaşi analist, în aceleaşi condiţii de lucru.

$$
r=2.8 \times s r
$$

where: $s r=$ standard deviation of repeatability.

în care: $s r=$ deviaţia standard a repetabilităţii.

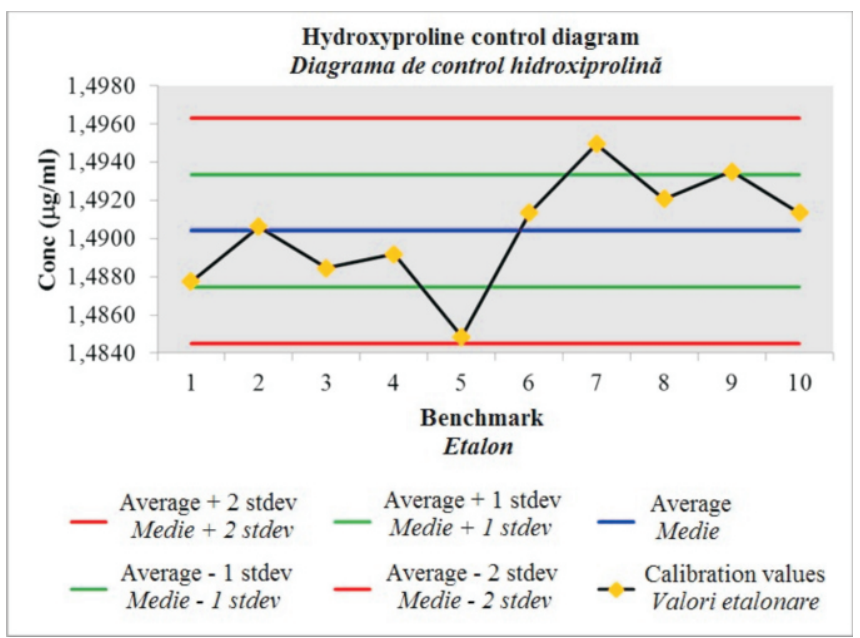

Figure 3. Hydroxyproline control diagram

Figura 3. Diagrama de control a hidroxiprolinei 
The control diagram shows that eight of the replicated samples fall into the average limit +1 standard deviation, and only two range between the average +2 standard deviations, which means good repeatability.

We consider that the method has good repeatability, because standard deviation fell into the $0.00280-0.00298 \mu \mathrm{g} / \mathrm{mL}$ range.

In terms of internal reproducibility, replicated determinations were performed on the same analyte, under the same conditions imposed by the method, by the same analyst, on different days and the following were calculated for each determination: average, standard deviation, relative standard deviation (RSD).
Din diagrama de control se observă că 8 dintre probele replicate se încadrează în limita medie +1 deviaţie standard şi doar două sunt cuprinse în medie + 2 deviaţii standard, ceea ce reprezintă o bună repetabilitate.

Considerăm că metoda are o bună repetabilitate deoarece deviaţia standard s-a încadrat în intervalul 0,00280-0,00298 $\mu \mathrm{g} / \mathrm{ml}$.

În ceea ce priveşte reproductibilitatea internă, s-au realizat determinări replicate pe acelaşi analit, în aceleaşi condiţii impuse de metodă, de acelaşi analist, în zile diferite şi s-au calculat pentru fiecare determinare: media, deviaţia standard, deviaţia standard relativă (RSD).

$$
\mathrm{RL}=2,8 \times 1,6 \times \mathrm{sr}=1,6 \times r
$$

where:

$\mathrm{sr}=$ standard deviation of repeatability

$r=$ repeatability

Ten repeated analyses of samples with the concentration of $1.5 \mathrm{\mu g} / \mathrm{L}$ hydroxyproline were performed within ten days and $\mathrm{Yi}$ values of signal intensity at $558 \mathrm{~nm}$ were measured. Based on the equation of the calibration curve, $X i$ values of concentration experimentally obtained were calculated. în care:

$\mathrm{sr}=$ deviaţia standard a repetabilităţii

$r=$ repetabilitatea

S-au efectuat 10 analize repetate ale probelor de concentraţie $1,5 \mu \mathrm{g} / \mathrm{ml}$ hidroxiprolină în intervalul a zece zile şi s-au măsurat valorile Yi ale intensităţii semnalului de la $558 \mathrm{~nm}$. Pe baza ecuaţiei curbei de etalonare s-au determinat prin calcul valorile $\mathrm{Xi}$ de concentraţie obţinute experimental.

Table 4: $Y i$ and $X i$ values obtained for the ten analysed samples

Tabelul 4: Valorile Yi şi Xi obţinute pentru cele 10 probe analizate

\begin{tabular}{c|c|c|c|c|c|c|c|c|c|c|c|} 
& 1 & 2 & 3 & 4 & 5 & 6 & 7 & 8 & 9 & 10 \\
\hline \hline $\mathrm{Yi}$ & 0.2350 & 0.2354 & 0.2358 & 0.2380 & 0.2345 & 0.2367 & 0.2366 & 0.2342 & 0.2370 & 0.2368 \\
\hline $\mathrm{Xi}$ & 1.4789 & 1.4905 & 1.4933 & 1.5082 & 1.4845 & 1.4913 & 1.4949 & 1.4921 & 1.4935 & 1.4913 \\
\hline
\end{tabular}

$$
\mathrm{X}_{\text {average }}(\text { det. })=1.4946 \mu \mathrm{g} / \mathrm{L}
$$$$
\mathrm{s}=0.008279 \mu \mathrm{g} / \mathrm{mL}
$$

$\mathrm{R}=1.6 \times 0.008279=0.013246 \mu \mathrm{g} / \mathrm{mL}$

RSDR $=0.8863 \%$

For tested concentrations, $R>r$ and within the permissible limits.

From the calculation of performance parameters of the studied method, the following are noted:

- The linearity range of the method was between $0.5-2 \mu \mathrm{g} / \mathrm{mL}$, interval where the value of the

$$
\begin{aligned}
& X_{\text {mediu }}(\text { det. })=1,4946 \mu \mathrm{g} / \mathrm{l} \\
& \mathrm{S}=0,008279 \mu \mathrm{g} / \mathrm{ml} \\
& \mathrm{R}=1,6 \times 0,008279=0,013246 \mu \mathrm{g} / \mathrm{ml} \\
& \mathrm{RSDR}=0,8863 \%
\end{aligned}
$$

Pentru concentraţiile testate, $R>r$ şi este situat în limitele admise.

Din calculul parametrilor de performanţă ai metodei studiate se observă următoarele:

- Domeniul de liniaritate al metodei este cuprins între 0,5-2 $\mathrm{\mu g} / \mathrm{ml}$, interval în care valoarea 
correlation coefficient was 0.9906 ;

- If one takes into account smaller concentrations, the value of the correlation coefficient is 0.9903;

- Limit of detection was set for a concentration of $0.1088 \mu \mathrm{g} / \mathrm{mL}$;

- Limit of quantification was set for a concentration of $0.1295 \mu \mathrm{g} / \mathrm{mL}$;

- Accuracy is $99.36 \%$ and represents closeness between the real value and the determined value in the analysed sample;

- Standard deviation value is $0.00285 \mu \mathrm{g} / \mathrm{mL}$.

\section{CONCLUSIONS}

The paper presents a method for determination of hydroxyproline in protein biomaterials for medical use.

The method was validated in order to establish performance parameters and check compliance to the set purpose by determining: linearity, limit of detection, limit of quantification, accuracy and reliability of the method.

The method was checked to ensure repeatability and reproducibility and is supported by determinations on collagen products for medical use - hydrolysates, gels, spongious matrices - from the Collagen Department of INCDTP - Division ICPI.

\section{Acknowledgements}

This study was funded by ANCSI within "Nucleu" Program 2016 - 2017, project code PN 163404 04, Contract 26/14.03.2016. coeficientului de corelaţie a fost 0,9906;

- Dacă se iau în calcul şi concentraţiile mai mici, valoarea coeficientului de corelaţie este 0,9903 ;

- Limita de detecţie a fost stabilită pentru o concentraţie de $0,1088 \mu \mathrm{g} / \mathrm{ml}$;

- Limita de cuantificare a fost stabilită pentru o concentraţie de 0,1295 $\mu \mathrm{g} / \mathrm{ml}$;

- Exactitatea este de 99,36\% şi reprezintă apropierea dintre valoarea reală şi valoarea găsită în proba de analizat;

- Deviaţia standard are valoarea de 0,00285 $\mu \mathrm{g} / \mathrm{ml}$.

\section{CONCLUZII}

Lucrarea prezintă o metodă de determinare a hidroxiprolinei din biomateriale proteice de uz medical.

Metoda a fost validată pentru a se stabili parametrii de performanţă şi pentru verificarea conformării cu scopul propus prin determinarea: liniarităţii, limitei de detecţie, limitei de cuantificare, exactitatea şi fidelitatea metodei.

Metoda a fost verificată pentru a se asigura repetitivitatea şi reproductibilitatea şi este susţinută de determinări pe produse colagenice de uz medical - hidrolizate, geluri, matrici spongioase - provenite din Departamentul de Colagen al INCDTP - Sucursala ICPI.

\section{Mulţumiri}

Acest studiu a fost finanţat de ANCSI în cadrul Programului Nucleu 2016 - 2017, cod proiect PN 1634 04 04, Contract 26/14.03.2016.

\section{REFERENCES}

1. Albu, M.G., Titorencu, I., Chelaru, C., The stability of some collagen hydrohels, Revista de Pielărie Încălţăminte (Leather and Footwear Journal), 2011, 11, 1, 11-20.

2. Albu, M.G., Titorencu, I., Biocompatibility study of collagen nerve conductors, Revista de Pielărie Încălţăminte (Leather and Footwear Journal), 2011, 11, 4, 329-340. 
3. Albu, M.G., Ghica, M.V., Tang, K., Liu, J., Coara, Gh., Rheological behavior of some collagen extracts, Revista de Pielărie Încălţăminte (Leather and Footwear Journal), 2012, 12, 3, 193-200.

4. Vranceanu, M.D., Saban, R., Albu, M.G., Antoniac, I., Preparation and characterization of collagen: amorphous calcium phosphate composites, Revista de Pielărie Încălţăminte (Leather and Footwear Journal), 2012, 12, 3, 215222.

5. Albu, M.G., Leca, M., Trandafir, V., Rheological behaviour of some collagen creams, Revista de Pielărie Încălţăminte (Leather and Footwear Journal), 2012, 12, 4, 257-270.

6. Albu, M.G., Deselnicu, V., Ioannidis, I., Deselnicu, D.C., Chelaru, C., Chemical functionalization and stabilization of type I collagen with organic tanning agents, Korean J Chem Eng, 2015, 32, 2, 354-361, DOI: 10.1007/s11814-0140197-x.

7. Albu, M.G., Trandafir, V., Leca, M., Carsote, C., Characterization of collagen-gentamicin systems used in controlled release of drugs, Revista de Pielărie Încălţăminte (Leather and Footwear Journal), 2007, 4, 3-9.

8. Albu, M.G., Ficai, A., Lungu, A., Preparation and characterization of collagen matrices obtained at different freezing temperatures, Revista de Pielărie Încălţăminte (Leather and Footwear Journal), 2010, 10, 3, 39-50.

9. Shoulders, M.D., Raines, R.T., Collagen structure and stability, Annu Rev Biochem, 2009, 78, 929-958.

10. Bhattacharjee, A., Bansal, M., Collagen Structure: The Madras Triple Helix and the Current Scenario, Life, 2005, 57, 3, 161-172.

11. International Standards Organisation, Methods of Test for Meat and Meat Products. Part II. Determination of L(-)hydroxyproline Content, ISO 3496: 1994.

12. Mee, J.M.L., Specific assay of hydroxyproline by gas chromatography, J Chromatog, 1973, 87, 155-161.

13. Pefier, C., Ronziere, M.C., Rattner, A., Frey, J., Employment of gas liquid chromatography for the analysis of collagen amino acids in biopsy tissue, J Chromatog, 1980, 182, 155-162.

14. Afkhami, A. Madrakian, T., Maleki, A., Indirect Kinetic Spectrophotometric Determination of Hydroxylamine Based on Its Reaction with lodate, Anal Scien, Feb. 2006, 22, 329-331.

15. Qi, X., Baldwin, R.P., Liquid chromatography/electrochemical detection of hydroxylamines by oxidation at a cobalt phthalocyanine chemically modified electrode, Electroanal, 1994, 6, 5-6, 353-360.

16. Partridge, S.M., Elsden, D.F., Rapid methods for the determination of glucosamine, galactosamine and hydroxyproline, Biochem J, 1961, 80, 34.

17. Mussini, E., Marcucci, F., Separation of prolines and hydroxyprolines by gas chromatography, J Chromatog, 1965, 20, 266-269.

18. MacKenzie, S.L., Tenaschuk, D., Analysis of hydroxyproline and hydroxylysine: improved gas chromatographic method, J Chromatog, 1975, 104, 176-177.

19. Woessner, J.F., Woessner, J.R., Arch Biochem Biophys, 1961, 93, 440.

20. Bergman, I., Loxley, R., Anal Chem, 1970, 42, 703.

21. Ignat'eva, N.Yu., Danilov, N.A., Averkiev, S.V., Obrezkova, M.V., Lunin, V.V., Sobol, E.N., Determination of Hydroxyproline in Tissues and the Evaluation of the Collagen Content of the Tissues, J Anal Chem, 2007, 62, 1, 51-57.

22. Carlson, C.G., Determination of hydroxyproline content as a measure of fibrosis in nondystrophic and dystrophic skeletal muscle, Wellstone Muscular Dystrophy Center Washinton, DC, 2014, 1-10.

23. AOAC International, in P. Cunniff (ed.), Official methods of analysis of AOAC international, 1996, 16th ed., 39.1-39.6, Gaithersburg, MD: AOAC International.

24. http://www.sigmaaldrich.com/technicaldocuments/protocols/biology/hydroxyproline-assay-kit-mak008.html 2016

25. http://www.scientistsolutions.com/forum/biochemistry-assay-development-protocols/hydroxyproline-assay 
26. CEN/TC 289/WG 1 - NWIP Leather - Chemical tests - Determination of the designation "leatherboard" by a gravimetric method - determination of hydroxyproline in leather fiberboard - draft 2012.

27. Etherington, D.J., Sims, T.J., Detection and Estimation of Collagen, J Sci Food Agric, 1981, 32, 539-546.

Article received/Data primirii articolului: 26.05.2016

Accepted/Acceptat la data: 14.06 .2016 